VAKANÜVIS- Uluslararası Tarih Araştırmaları Dergisi/ International Journal of Historical Researches, Yıl/Vol. 1, Sayı/No. 2 Güz/Fall 2016 ISSN: 2149-9535

\title{
Kitap Tanıtımı/ Book Review: Taner Bilgin, Bir Türk Beyi Ebulfez Elçibey
}

\section{Aslıhan Kılınç ${ }^{1}$}

Azerbaycan tarihi hakkında günümüze kadar sayısız eser kaleme alınmış ve bu eserlerin birçoğunda, gerek Azerbaycan tarihinde Türklerin rolü, gerekse Türklerin bu topraklar için ödediği bedel hakkında birçok bilgi verilmiştir. Bilecik Şeyh Edebali Üniversitesi Tarih Bölümü Öğretim Üyesi Yrd. Doç. Dr. Taner Bilgin tarafından yazılmış olan bu eserde ise Türklerin Azerbaycan coğrafyasında, tarihlerindeki en ağır bedelleri ödeyerek verdikleri ve hala da devam eden kanlı bir sınav olan "Karabağ Meselesi" ustaca kaleme alınmıştır. Ayrıca Azerbaycan Milli Mücadelesinde ilk akla gelen isim olan Ebulfez Elçibey'in bu bağımsızlık uğrunda nasıl bir çaba sarf ettiği de bu çalışmada en ince ayrıntılarıyla ele alınmaya çalışımıştır.

Eserde en çok göze çarpan nokta ise Ebulfez Elçibey'in Atatürk ve Türkiye hayranlığıdır. Öyle ki "Men Atatürk'ün Esgeriyem" sözü onun dilinden hiç düşmemektedir ve sorulduğu zaman "Azeri" kelimesinden çok "Biz Türk'üz" sözü ile kimliğini belirtmesi ise Türk'lerinde ona hayran olmasında önemli rol oynamıştır. Özellikle Cumhuriyet Tarihi alanında birçok çalışması olan yazar bu eserinde de Türklerin bulunduğu coğrafya üzerinde başta Rusya olmak üzere birçok batılı devlete karşı nasıl bir varoluş mücadelesi verdiklerini ve Ebulfez Elçibey'in bu mücadeledeki rolünü akıcı bir dille ortaya koymuştur.

Azerbaycan tarihi ve bu topraklar için verilmiş olan bu mücadeleye geçmeden önce kitabın ilk bölümünde bu ülkeye ömrünü adamış olan Ebulfez Elçibey'in hayatı kısa başlıklarla anlatılarak bu eşsiz devlet adamı tanıtılmıştır. Oldukça zor yıllar geçiren Elçibey çocuk yaşta babasını kaybetmiş ve dayısının yanında büyümüştür. Illkokuldan itibaren zor şartlarda eğitim hayatına başlamasına rağmen tüm zorluklara göğüs germesini bilmiş ortaokul ve lise den sonra, yılmadan tahsiline Azerbaycan Devlet Üniversitesi Şarkiyat Araştırmaları

\footnotetext{
${ }^{1}$ Doktora Öğrencisi, Bilecik Şeyh Edebali Üniversitesi Sosyal Bilimler Enstitüsü Tarih Anabilim Dalı, asI-han-7701@hotmail.com.
}

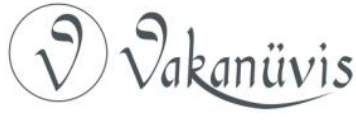


bölümünde devam etmiştir.(s.15-31) Elçibey, Sahip olduğu Milli görüş nedeni ile üniversite yılarında oldukça zor günler geçirecektir. Buna rağmen bedel ödemekten çekinmeyecek ve benimsediği çizgiden ödün vermeden ülküsünü savunmaya devam edecektir. Üniversite yıllarında en büyük idolü olan Mehmet Emin Resulzade'nin yolunda ilerleyen Elçibey, ülkesinin içinde bulunduğu çıkmazın farkındadır ve arkadaşları ile bu gidişata dur demek için bir şeyler yapmalıdır. Tabi ki bu girişimleri, (protestoları, gizli toplantıları) Sovyet Rusya'sı tarafından da fark edilecek ve Elçibey KGB Zindanları ile tanışacaktır. Yine de üniversite yılları boş geçmemiştir ona göre sadece daha programlı bir teşkilat gereklidir artık ve buda AHC'nin (Azerbaycan Halk Cephesi) kurulması ile tamamlanacaktır.

Eserin ikinci bölümüne gelindiğinde görüyoruz ki Ebulfez Elçibey Milli Şuuru uyandırma çalışmalarında oldukça fazla yol kat etmiştir. Çünkü Sovyet Rusya onun bu çalışmalarından rahatsız olmuş ve önünün kesilmesi gerektiğine karar vermiştir. Tutuklanarak 1,5 yıl KGB Zindanlarında taş ocaklarında işkenceye maruz bırakılmıştır. Öldürülmek bile istendiği bu zindanlarda ve tutukluluk sürecinde, düşünmeye de fırsat bulan Elçibey, dava arkadaşlarının da bireysel olarak hayatlarına yön verdiğini görünce, birtakım radikal kararlar alır.

Tutukluluk süreci bitince ilk olarak evlenir ve iki çocuğu olur. Her ne kadar grupları dağılmış olsa da azaldık harekâtı tüm hızıyla devam etmektedir ve Elçibey'de bu harekâtın ilk ve en önemli ismi olmuştur. Çalışmalarını daha da hızlandıran Elçibey, artık daha da teşkilatlı çalışmanın gereğinin farkındadırlar ve böylece AHC'yi kurmaya karar vererek yeni bir çalışma programı hazırlar. Azadlık hareketinin giderek güçlendiği bu dönem ise Sovyetler Rusyası'nın dağılma sinyalleri verdiği yıllar olmuştur.

Eserde yazarın üstüne basarak vurgulamaya çalıştığı bu "Türk Beyi" nin hayatı birçok yönü ile binlerce Azeri ve Türk'e ibretlik bir hayat hikâyesini gözler önüne sermiştir. Ömrünün en güzel yıllarını, kabullendiği ideolojisi uğruna zindanlarda ve sokaklarda işkence ile geçiren bu Türk Beyi, resmi olarak iki yıla, aslında ise ömrünü harcadığı bu yıllara sığdırdığı Türk Sevdasının en zor sınavını beklide Karabağ da, Yanvar katliamında verecektir. Ermeniler tarafından katledilen onca Türk'ün ahını omuzlarında yük olarak taşıyan Elçibey, nihayet 
Azerbaycan'ın bağımsızlığını kazanması ve Cumhurbaşkanı olarak seçilmesi ile bu kutlu ülküde ki başrolünü alacaktır. (Ekim 1991) (s.112)

Üçüncü bölüm her ne kadar Azerbaycan'ın bağımsızlığını kazandığı bölüm olarak ele alınsa da aslında komünizmin etkisi hala devam etmektedir ve göz ardı edilmemesi gereken bir husus ise Rusya ne kadar Azerbaycan için önemli bir devlet olmuşsa, Azerbaycan da Rusya için bir o kadar önemli bir devlet olmuştur.

Bu bölümde yazarın üzerinde durduğu bir diğer önemli nokta ise Ebulfez Elçibey'in nasıl bir Türkiye ve Atatürk sevdalısı olduğudur. "Men Atatürk'ün Esgeriyem" sözü ve ölümünden sonra Bakü'de ki mütevazı evinde, derme çatma eşyaları arasında sahip olduğu tek takım elbise üzerinden çıkan Atatürk rozeti onun bu sevdasının en güzel örneği olmuştur.(s.136-137) Cumhurbaşkanı olarak seçilmesinden 16 gün sonra ilk yurt dışı ziyaretini Türkiye'ye gerçekleştiren Elçibey, ikinci ziyareti sonrasında hava alanından Bakü’ye gitmek üzere ayrılacağı saatlerde yaptığı konuşmasında, Türkiye ve Azerbaycan devletlerinin kardeşliğini, iki bayrak tek Millet vurgusunu yaparak, Türk Milletinin bölünmez bütünlüğünü bir kez daha tüm dünya ya duyurmuştur.

Yazar kitabının son bölümünde konuyu tüm yönleri ile ele alarak hem Azerbaycan coğrafyası ve bu coğrafya üzerinde ki siyasi mücadeleler üzerinde durmuş, hem de bu siyasette etkin rol oynayan Elçibey'in Azerbaycan'ın var oluş sürecinde, tarihine nasıl yön verdiğini en açık hali ile yazıya dökmüştür. Başta Sovyet Rusya'nın ve İran'ın Azerbaycan üzerindeki emelleri ve bunların gerçekleştirilmesi uğrunda uyguladıkları kanlı siyasetin sebep olduğu katliamları (Hocalı Katliamı) tüm ayrıntıları ile anlatan yazar kitabında bu konuya geniş yer vermiştir. Bölümde yer alan diğer bir başlık olan Elçibey'in Cumhurbaşkanlığından ayrılması kısmında, Yazar, Ebulfez Elçibey'in kişiliğini ön plana çıkararak olması gerektiği gibi bir Türk Bey'inin Vatanı için gerekirse canı da dâhil olmak üzere her türlü varlığından vazgeçebilmesi gerektiği vurgusunu yapmaktadır. Elçibey'in "Bana hiçbir şey lazım değil. Bir tek isteğim vardı ki iç savaş olmasın. Soydaşlarımız Kandaşlarımız birbirini öldürmesin." (s.193) Sözü ile kardeşkanı dökülmektense iktidarı bırakıp Keleki'ye gitmesi de milletine düşkünlüğünün bir simgesidir. Kanser tedavisi görmesi

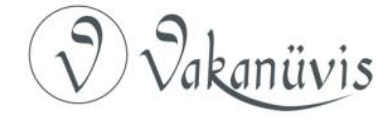


gerekirken Keleki deki evinde ortamın durulmasını beklerken bir nevi kendi ölümünü de beklemiştir Elçibey. Hastalığının giderek ilerlemesi ve durumunun ağırlaşması ile GATA da (Gülhane Askeri Tıp Akademisi) tedavi altına alınır anacak hastalığı Keleki de oldukça ilerlemiştir ve 22 Ağustos 2000 tarihinde hayata gözlerini kapatır.(s.212)

Sonuç olarak Yazarın "Türk Sevdalısı Türk Beyi'in Türkiye'de Ölümü" ve "Beyoğlu Bey'e Veda " başlıkları ile sonlandırdığı bu bölüm ile Azerbaycan direniş tarihinin en önemli ismi Ebulfez Elçibey'in hayatı en açık ve en akıı hali ile anlatılmaya çalışılmıştır. Eserin tamamında hem Milli mücadele ruhu üzerinde durulmuş hem de bu direnişin başını çeken bir liderin hayatı örneklerle ve görsellerle hafızalara kazınmaya çalışılmıştır. Çalışma Türk-Ermeni meselesine ışık tutan bilgiler içermesi açısından da önemli bir eserdir. Özellikle Hocalı Katliamı, Yanvar Meselesi, Gence Baskınının ele alındığı bölümler Ermeni zulmünü gözler önüne sermektedir. Tarih boyunca Azerbaycan ve Türk Cumhuriyetlerinin kanayan yarası olan Dağlık Karabağ Meselesi de eserde yazar tarafından oldukça realist bir şekilde ele alınmış ve konunun hassasiyetine vurgu yapılmıştır. 